\title{
Becoming the mother of a child with disabilities: A systematic literature review
}

\author{
N.C. van Wyk and R. Leech \\ Department of Nursing Science, University of Pretoria, South Africa
}

\begin{abstract}
The transition to motherhood starts early in pregnancy and is completed when the mother feels competent in caring for the infant. Becoming the mother of a child with disabilities is demanding as their needs are complex. The aim of the review was to appraise completed qualitative and quantitative reports on the challenges of mothers of children with disabilities regarding their own transition to motherhood. A review of the literature was carried out through, first, a computerized search strategy to identify relevant studies from selected databases and, second, quality appraisal and thematic analysis of selected studies. The transition to motherhood of children with disabilities takes place in the inside world at home, the outside world external to home and the 'going-between' world of travelling between the two worlds. The mothers are challenged at home to integrate basic infant care with technical care of their children. In the outside world they often struggled to ensure that their children got the necessary professional care. Travelling between their homes and healthcare services posed many problems.
\end{abstract}

La transition vers la maternité commence au début de la grossesse et la transition s'est terminé quand la mère est compétente pour être capable de soigner pour l'enfant. De devenir la mère d'un enfant handicapé est exigeant parce que leurs besoins sont complexes. L'objectif de l'étude était d'évaluer à la fin les rapports qualitatives et quantitatives sur les défis de mères d'enfants handicapés en ce qui concerne leur propre transition vers la maternité. Une revue de la littérature a été réalisée par le biais, d'abord, une stratégie de recherche informatisé pour identifier les études pertinentes à partir de bases de données sélectionnées et, deuxièmement, l'évaluation de la qualité et de l'analyse thématique des études sélectionnées. La transition vers la maternité des enfants handicapés a lieu dans le monde dans la maison, le monde dehors de la maison et dans le monde "qui se trouve entre ces deux mondes " c.a.d. le monde de voyage entre ces deux mondes. Les mères sont contestées à la maison pour intégrer les soins de bases comme les nourrissons avec un soin technique de leurs enfants. Dans le monde dehors de la maison, ils ont souvent lutté de donner la securité à ce que leurs enfants ont obtenu les soins nécessaires qui doivent être professionnels. De voyager entre leur domicile et les services de soins de santé a posé beaucoup de problèmes.

Key words: transition to motherhood; infants with disabilities; care at home; care outside home; systematic review

Mots clés: la transition vers la maternité; les enfants handicapés; les soins à domicile; la maison de soin dehors de la maison; Revue systématique 


\section{Introduction}

New motherhood is a period of transition (Barkin \& Wisner, 2013). First-time mothers experience the transition as challenging (Darvill, Skirton, \& Farrand, 2010) as they come to terms with the implications of having to take care of (Basnyat \& Dutta, 2012) and becoming attached to their babies (Fourquier, 2011) within a specific cultural context (Kennedy et al., 2014). Culture determines the views of people regarding motherhood and the caring for children (McQuillan, Griel, Shreffler, \& Tichenor, 2008). Although there are many similarities in how new mothers in a cultural group experience the transition to motherhood it remains a personal and unique experience for each individual (Nelson, 2003).

\section{Background}

Women who desire to have children consider motherhood as intertwined with womanhood (Park \& Hill, 2014) and view becoming a mother as a natural progression of adult femininity (Mahler \& Saungeres, 2007). Giving birth means to them a transformation from being selfish young adults into selfless mothers (Malacrida \& Boulton, 2012).

Selflessness being synonymous with motherhood (Barkin \& Wisner, 2013) is in accordance with a traditional gendered expectation that women should first be wives and mothers. Should there be time mothers should be part-time involved in employment (Jacques \& Radtke, 2012). This expectation is currently still supported by some young female adults who plan to become mothers. A study by Herman, Lewis and Humbert (2013) of young women scientists and engineers found that they willingly sacrificed career opportunities and progression after the birth of their children. A group of psychology female students in a study by Jacques and Radtke (2012) expressed their right to choose their own life paths, which included what they called intensive mothering. They wanted to put their children first and their professions second.

Many mothers view selflessness as a requirement of good parenting (Hey \& Bradford, 2006) to the extent that their lives get organized around their children (Read, Crockett, \& Mason, 2012) and all other mothers who do not do the same are labelled by them as bad mothers (Fouquier, 2011). The media contributes to the ideal image of mothers by portraying them as selfless and at the same time slim, tastefully dressed and always happy (Hadfield, Rudoe, \& Sanderson-Mann, 2007). These myths lead to many mothers feeling inadequate (Choi, Henshaw, Baker, \& Tree, 2005), as they cannot live up to the expectations (Sevón, 2012). For many new mothers motherhood comes as a shock. It is very different from what they expected and they are often surprised that their friends or the nurses at the clinics had not warned them about the many challenges (Read et al., 2012). 
Maternal distress is experienced when the challenges of motherhood cause the women to have feelings of anger (Fouquier, 2011), anxiety and depression (Rallis, Skouteris, McCabe, \& Milgrom, 2014). It can happen during pregnancy or in the postpartum period (Van Bussel, Spitz \& Demyttenaere, 2008) when body dissatisfaction contributes to occurrence of maternal distress (Clark et al., 2009). Social disadvantages such as difficult financial circumstances enhance the risk of distress (Morgan \& Eastwood, 2012). Women with a history of depression (Britton, 2008) and poor partner support (Milgrom, 2008) may find it challenging to cope with the demands of motherhood. The additional role, namely that of motherhood that they have to fulfil, may deplete their coping resources (Emmanuel \& St John, 2010).

Vulnerable mothers are at an even greater risk of not being able to cope with motherhood. Single women and those who experience inadequate support from family often experience feelings of desperation and hopelessness at the birth of their babies (Muňoz et al., 2013). Adolescent mothers are considered to be too young for the demands of motherhood (Wilson \& Huntingdon, 2006) and women who delay motherhood may develop complications during pregnancy and birth and may find it difficult to change their lifestyles to accommodate babies (Shelton \& Johnson, 2006).

Women who give birth to children with disabilities are also vulnerable. Answers to the question of whether their circumstances force them to be even more selfless than mothers with babies without disability are not readily available. The transition to motherhood is, according to Mercer (2004), completed when the mothers feel confident in taking care of their infants. The period is often longer when infants with disabilities are born. The situations that these mothers have to adjust to are much more complicated and the needs of the infants are much more complex than in the case of the birth of infants without disability. Most mothers with children with disabilities only become confident to care for them when the children are six years old (Azad, Blacher, \& Marcoulides, 2013).

\section{Aim}

The authors aimed to study existing research reports on the challenges that mothers of children with disabilities experience in their transition to motherhood.

\section{Method}

A review of literature was carried out through a computerized search strategy to identify relevant studies from the following databases: ACADEMIC SEARCH PREMIER, SCIENCE DIRECT, SPRINGERLINK and TAYLOR AND FRANCIS from 2004 to 2014. The search terms used were 'transition to motherhood', 'being mothers', 'becoming mothers' and 'children with disabilities'. 
The inclusion criteria for studies to be included in the review were: 1) written in English; 2) published in a peer-reviewed journal; 3) a focus on the transition to motherhood; and 4) a focus on the period from birth until the children were about seven years old. According to the exclusion criteria, editorials, expert opinions and literature reviews were not included as resources for the review.

The initial search delivered a total of 1513 reports; 89 from ACADEMIC SEARCH PREMIER, 424 from SPRINGERLINK, 885 from SCIENCE DIRECT, and 115 from TAYLOR AND FRANCIS. The total number of reports was initially reduced manually by screening the reports' titles and abstracts independently, using the inclusion and exclusion criteria. Through a discussion of the outcome of the screening process consensus was reached on the final number of reports: this number comprised 3 from ACADEMIC SEARCH PREMIER; 10 from SPRINGERLINK; 15 from SCIENCE DIRECT; and 25 from TAYLOR AND FRANCIS. The full text of the 53 reports was read and the number of reports was reduced to 10 . The excluded reports did not focus on the transition of women to become mothers of children with disabilities. Ten reports focused specifically on the transition to motherhood of women who gave birth to children with disabilities. The reports were from studies that had been done in the United States of America, United Kingdom, Brazil and Belgium.

The information from the selected reports was summarized according to the authors, year of publication, research setting, research design, participants, and research methods (Table 1).

\section{Quality appraisal of the reports}

The focus of each article chosen was the methodological strengths and weaknesses and a consideration of the worth of the paper in terms of the transition to motherhood when a child with disability is born. Appropriate appraisal checklists were used to assist with the rigour of this process: the 22-item STROBE for quantitative cohort studies (Von Elm et al. 2007; Strobe statement 2007 http://www.strobe-statement.org/index.php?id=available-checklists): the 22-item STROBE for crosssectional studies (Von Elm et al. 2007; Strobe statement 2007 http://www.strobestatement.org/index.php?id=available-checklists); and the 32-item COREQ for qualitative studies (Tong, Sainsbury \& Craig, 2007).

The articles appraised with the COREQ scored between 12 and 22 out of the 32 criteria. The criteria of the checklist were the provision of insufficient information, the relationship of the researchers with the participants, how participants were approached, how many people refused to participate, and the data collection method. 
All of the STROBE-evaluated articles met at least 15 of the 22 STROBE statement criteria. However, variables, potential sources of bias, the timing of data collection, and how the sample size was determined were rarely mentioned. The titles of the studies did not always provide sufficient information about the study design.

Of the ten studies included, two studies (one quantitative cross-sectional study, and one mixedmethod study) were evaluated using the STROBE checklists and nine studies (six qualitative studies, one mixed method study, one qualitative case study, and one secondary analysis of three qualitative studies) were evaluated using the COREQ checklist. In-depth and semi-structured interviews were mainly used in the qualitative studies for data collection. In the quantitative studies existing instruments were used. See Table 1 for additional information.

\section{Analysis of the reports}

The review studies were analysed thematically according to the perspectives of Nicholl and Begley (2012) who describe the care of the child with disabilities as taking place in an "inside world at home, the outside world external to the home, and a 'going-between' world of travelling between the two worlds" (Refer to Table 2.) The differentiation of where the transition to motherhood takes place is in accordance with the ecological contexts for human development - the micro-system (the homes of the mothers); the meso-system (the relationship between micro-systems); and the exosystem (the work-environment of the mothers and the healthcare services and social services that they use for their children); and the macro-systems (the perspectives of people based on their cultural perspectives that motherhood should lead to the development of healthy and responsible adults) (Garbarino \& Ganzel, 2000).

\section{Results}

The transition to motherhood took place in the inside world at home, in the outside world external to the home and in 'going-between' the inside and outside world.

\section{Transition to motherhood in the inside world at home}

The mothers of children with disabilities experienced challenges in integrating ordinary childcare activities, which they described as bathing and dressing, and maintaining the safety of the child (Nicholl \& Begley, 2012) with the technical care that their children required (Redmond \& Richardson, 2003). They had to develop technical care skills that are usually associated with nurses and 
physiotherapists to meet the needs of the children (McKeever \& Miller, 2004). In order to combine ordinary care with technical care they had to keep to very strict schedules (Redmond \& Richardson, 2003) and to ensure that the children receive the necessary treatment and therapy from the relevant service providers (Roskam \& Schelstraete, 2007).

The children in the review studies were fragile (Redmond \& Richardson, 2003) and often experienced health challenges that confronted their mothers with their possible deaths (Nicholl \& Begley, 2007). The mothers could only focus on the present, as future perspectives might not have existed (Bingham, Correa, \& Huber, 2012). In the transition to motherhood, when children without disabilities are born, the focus is on the future and the preparation of the children to become responsible adults (McKeever \& Miller, 2004). The mothers in the review studies, however, knew that their children would not develop into responsible independent adults because of their disabilities (Rogers, 2007), notwithstanding the inputs that they made in the day-to-day care of the children (Green, 2007) and the many sacrifices that they made to improve their situations (Landsman, 2005). Society unfortunately tends to devalue the motherhood of these women, as the outcome of their mothering is not associated with the rearing of productive citizens that contribute to society (McKeever \& Miller, 2004).

The mothers believed that only they could deliver the care that the children needed and that it should be delivered at home (Nicholl \& Begley, 2012). They were convinced that they knew their children and the needs of their children better than anyone else could (Redmond \& Richardson, 2003). In hospitals and other institutions their children would not get the quality individualized care that they could provide at home (Nicholl \& Begley, 2012).

The women considered themselves as the only people who were so connected to their children that they could understand their needs without the children communicating these to them (McKeever \& Miller, 2004). By watching them closely the women could tell when something was wrong or what the children needed. They watched them every minute of the day and were also aware of changes in their condition at night (Nicholl \& Begley, 2012).

Good mothering referred, according to the women, to their ability to cope with the demanding needs of their children while they considered themselves as bad mothers when they got tired and experienced their circumstances as challenging (Rogers, 2007). The participants in the study of Bingham, Correa and Huber (2012) were of the opinion that mothers are supposed to cope and to keep on coping notwithstanding the circumstances. The women who also had other children found coping with the demands of the children with disabilities and the needs of their other children very 
demanding. The participants in Green's (2007) study, who also had other children, tried their utmost best to create family dynamics as close as possible to normative.

The mothers of children with disabilities were very reluctant to admit that they found it difficult to cope with the demands of caring for their children. When they got irritated and lost their patience with the children they blamed their feelings on being tired rather than on not being able to cope (Fiamenghi, Vedovato, Meirelles, \& Shimoda, 2010). The children required much support and the mothers got tired of attending to all their needs (Seymour, Wood, Giallo, \& Jellett, 2013). The care that the children with disabilities needed was time consuming and exhausting (Green, 2007). The children did not become less dependent on their mothers as they got older and their care did not become less exhausting (Nicholl \& Begley, 2012). They got heavier and their disabilities became more obvious and impacted more negatively on their development to the extent that their care became more challenging (Rogers, 2007).

\section{Transition to motherhood in the outside world external to home}

The findings of the review indicated that the many demands on the time of the mothers of children with disabilities in many cases forced them to give up the employment that they had prior to the birth of the children or had to adjust to part-time employment (Redmond \& Richardson, 2003). While the fathers of the children carried on building their careers the mothers became the primary caregivers and thus had to re-adjust their expectations about furthering their careers (Green, 2007). Notwithstanding these sacrifices the mothers reported that they experienced many rewards in taking care of their children (Redmond \& Richardson, 2003) that they would not necessarily have experienced under other circumstances (Green, 2007).

In the selected studies the mothers wanted to keep the children at home and wanted to take care of them. They did not want to relinquish their main caring role (Redmond \& Richardson, 2003) by having their children admitted to full-time institutional care. Instead of feeling sorry for themselves they developed strong coping strategies and positive images of themselves because of their abilities to cope with the demands of being the primary caregiver of their children (McKeever \& Miller, 2004). The challenges that they had to cope with made them sensitive to the needs of others and thankful for the positive aspects of life that one could easily take for granted (Bingham et al., 2012).

The transition to motherhood of children with disabilities was made difficult through the fragmented care and poor support from healthcare services (Redmond \& Richardson, 2003). The women had to use different services on premises far apart and had to explain repeatedly the disability of their children and their needs to healthcare personnel (Green, 2007). They preferred coordinated care so 
that only one facility could be used for all the services that their children required. A lack of information regarding the available healthcare services also made it difficult for them to access some of the services to the detriment of the development of their children (Bingham et al., 2012).

The findings of the review emphasized the women's willingness to demand appropriate care for their children (McKeever \& Miller, 2004) in order to ensure that they got the best possible healthcare (Green, 2007). Although the review studies were conducted in countries that are well resourced regarding care facilities for people with disabilities, the mothers often had to repeatedly contact doctors, nurses and therapists to arrange treatment for their children (Nicholl \& Begley, 2012). Without such efforts their children would not have had the required care (Bingham et al., 2012). In the process the women often had to endure aggression from the healthcare personnel to the extent that they were threatened that their children would not get the care that they tried to get arranged due to the 'fights' that the women had to put up (McKeever \& Miller, 2004). The women were very frustrated with the hospital-based approaches to care that the healthcare personnel had prescribed to be carried out at home where the mothers had to improvise care to suit their circumstances (Bingham et al., 2012).

The women in the review studies got more support for their own needs from other parents in similar situations (Redmond \& Richardson, 2003) than from healthcare- and social services (Nicholl \& Begley, 2012) and their own extended family (McKeever \& Miller, 2004). They were of the opinion that people who do not have children with disabilities do not understand the challenges that mothers of disabled children have to face (Rogers, 2007). On the other hand the women often did not want people to know that they found it difficult to cope with challenges related to the disabilities of their children and thus pretended that they were fine and did not need any support (Redmond \& Richardson, 2003). They felt that they had no choice other than to deal with the challenges (Landsman, 2005).

In the outside world the women wanted their children to meet the requirements of what is expected of children and did everything in their power to dress them in such a way that their disabilities would be covered. They were willing to spend more money on the clothes of these children than on the clothes of their other children to show that the children with disabilities were worthy of good clothes (McKeever \& Miller, 2004). They also wanted them to do what children without disabilities were capable of doing. To prepare their children to be included in the outside world became of utmost importance to them (Fiamenghi et al., 2010), as they considered it as the only way that their children would escape the pain of being stigmatized by others (Green, 2007). The mothers tried to 
protect their children from being devalued and did not want them to be labelled as 'disabled' (Landsman, 2005).

\section{Transition to motherhood in the 'going-between' world of travelling between the two worlds}

The women experienced major challenges to travel between their homes and healthcare services. All the equipment that is required to support their children to sit upright, or to walk or to be pushed in had to be carried around (Nicholl \& Begley, 2012). Such encumbrances discouraged them from going outside their homes. They thus became isolated from others; even from their extended family members (Rogers, 2007). With sufficient support from social services temporary respite care at home could have changed the situation for them (Bingham et al., 2012).

When the mothers had to travel with their children with disabilities to other towns or cities they had to make sure that they were familiar with the location of the nearest local hospital for any emergency. They tried to pre-empt what care might be required and made the necessary arrangements before the visits (Nicholl \& Begley, 2012).

\section{Discussion}

The mothers of children with disabilities in the review studies had to overcome many obstacles at home, outside home and moving between home and the outside world. They responded in innovative positive ways to the challenges without complaining about the demands on their time, energy and family life. They did, however, acknowledge that they got very tired because of a lack of support from healthcare- and social services and from their extended families. They would have been able to cope better with respite care at home.

In the transition to become mothers of children with disabilities the women relied on professional healthcare personnel to support them in line with the medical model's perspective regarding disabilities. In the medical model the professional healthcare personnel are the experts in the care of people with disabilities and they should be consulted for diagnosis and advice on treatment and care (Landsman, 2005). The mothers of children with disabilities in the review studies considered medical care as very important for their children, but unfortunately they had to struggle to get the professional people to respond appropriately to their concerns about best care for their children. In the medical model concepts such as 'normal' and 'disabled' are used and a binary opposition between the two categories is implied. The child with disabilities should be treated through medical therapies as disability is considered as a medical problem (Landsman, 2005). Parents who support the medical model in dealing with their children with disabilities tend to be over-protective towards them (Woolfson, 2004). The mothers in the review studies did not want others to take care of their 
children as they believed that other people would not be able to deliver the same quality of care. They could be considered as over-protective.

Parents who want to be the primary carers of their children with disabilities can be supported by health care professionals. In participation-based care parents of children with disabilities are enabled to optimally take care of their children with disabilities at home. Therapists serve as consultants and assist parents to develop their capacity to take care of their children and to use necessary health care services (Palisano et al., 2012). In care based on permanency-planning children with disabilities and their family members are regularly assessed and support is planned to address the identified needs. A sense of belonging of the child is promoted, while the environment is continuously upgraded to enable the family to take care of the child. The goal is to ensure that the arrangement could be permanent (Johnson, Kastner \& Committee on Children with Disabilities, 2005). Without sufficient support the health of the family members deteriorate to the extent that they then can no longer take care of their children with disabilities that results in a disruption in care with detrimental effect on the quality of life of the children (Byrne et al., 2010). The support should focus on measures to enhance their physical and psycho-social well-being (Dixon et al., 2001).

The social model of disability focuses not on 'curing' the disability but on ensuring that people with disabilities have quality life. The emphasis is on removing barriers to making it easier for people with disabilities to function in society without any stigmatization (Woolfson, 2004). The participants in the review studies were concerned about the way that society would treat their children. It was important for them to integrate their children in society. A major obstacle that they identified for the optimal functioning of their children with disabilities was the fragmentation of healthcare and social services. When parents and when possible their children with disabilities are consulted when healthcare and social services are planned and they remain involved in the evaluation of the accessibility of the services optimal use of the services is ensured (Watson, Abbott \& Townsley, 2006). Poor accessibility of healthcare and social services reduce the use of it.

\section{Conclusion}

Mothers of children with disabilities tend to describe themselves as being better equipped to take care of their children than anybody else could. In the transition they had to make many sacrifices in a situation of 'no-choice' but to deal with the challenges. In their transition to motherhood they coordinated the care that their children required, as the services that healthcare and social service professionals were fragmented. Healthcare authorities should revise policies if necessary to deliver comprehensive coordinated care preferably in one facility to prevent travelling between facilities. 
With the necessary support the mothers could be enabled to deliver the care that they children need without jeopardizing their own health.

\section{References}

\section{*Studies included in the review}

Azad, G., Blacher, J., \& Marcoulides, G.A. (2013). Mothers of children with developmental disabilities: Stress in early and middle childhood. Research in Developmental Disabilities, 34, 34493459.

Barkin, J.L., \& Wisner, K.L. (2013). The role of maternal self-care in new motherhood. Midwifery, 29(9), 1050-1055.

Basnyat, I., \& Dutta, M.J. (2012). Reframing motherhood through the culture-centered approach: Articulations of agency among young Nepalese women. Health Communication, 27(3), 273-283.

*Bingham, A., Correa, V.I., \& Huber, J.J. (2012). Mothers' voices: Coping with their children's initial disability diagnoses. Infant Mental Health Journal, 33(4), 372-385.

Britton, J.R. (2008). Maternal anxiety: Course and antecedents during the early postpartum period. Depression and Anxiety, 25(9), 793-800.

Byrne, M.B., Hurley, D.A., Daly, L., \& Cunningham, C.G. (2010). Health status of caregivers of children with cerebral palsy. Child: Care, Health and Development, 36(5), 696-702.

Choi, P., Henshaw, C., Baker, S., \& Tree, J. (2005). Supermum, superwife, supereverything: Performing femininity in the transition to motherhood. Journal of Reproductive and Infant Psychology, 23(2), 167-180.

Clark, A., Skouteris, H., Wertheim, E., Paxton, S., \& Milgrom J. (2009). The relationship between depression and body dissatisfaction across pregnancy and the postpartum: A prospective study. Health Psychology, 14, 27-35.

Darvill, R., Skirton, H., \& Farrand, P. (2010). Psychological factors that impact on women's experiences of first time motherhood: A qualitative study. Midwifery, 26, 357-366.

Dixon, L., McFarlane, W.R., Lefley, H., Lucksted, A., Cohen, M., Falloon, I., Mueser, K., Miklowitz, D., Solomon, P., \& Sondheimer, D. (2001). Evidence-based practices for services to families of people with psychiatric disabilities. Psychiatric Services, 52, 903-910.

Emmanuel, E., \& St John, W. (2010). Maternal distress: A concept analysis. Journal of Advanced Nursing, 66(9), 2104-2115).

*Fiamenghi, G.A., Vedovato, A.G., Meirelles, M.C., \& Shimoda, M.E. (2010). Mothers' interaction with their disabled infants: two case studies. Journal of Reproductive and Infant Psychology, 28(2), 191-199. 
Fouquier, K.F. (2011). The concept of motherhood among three generations of African American Women. Journal of Nursing Scholarship, 43(2), 145-153.

Garbarino, J., \& Ganzel, B. (2000). The human ecology of early risk. In Handbook of Early Childhood Intervention. $2^{\text {nd }}$ Edition. Ed by Shonkoff, JP \& Meisels, SJ. Cambridge University Press, Cambridge.

*Green, S.E. (2007). "We're tired, not sad": Benefits and burdens of mothering a child with a disability. Social Science \& Medicine, 64, 150-163.

Hadfield. L., Rudoe, N., \& Sanderson-Mann, J. (2007). Motherhood, choice and the British media: A time to reflect. Gender and Education, 19(2), 255-263.

Herman, C., Lewis, S., \& Humbert, A.L. (2013). Women scientists and engineers in European companies: Putting motherhood under the microscope. Gender, Work and Organization, 20(5), 467478.

Hey, V., \& Bradford, S. (2006). Re-engineering motherhood? Sure Start in the community. Contemporary Issues in Early Childhood, 7(1), 53-67.

Jacques, H.A.K., \& Radtke, H.L. (2012). Constrained by choice: Young women negotiate the discourse of marriage and motherhood. Feminism \& Psychology, 22(4), 443-461.

Johnson, C.P., Kastner, T.A., \& Committee on Children with Disabilities. (2005). Helping families raise children with special health care needs at home. Pediatrics, 115(2), 507-511.

Kennedy, V.L., Serghides, L., Raboud, J.M., DeSheng, S., Blitz, S., Hart, T.A., Walmsley, S.L., Angel, J.B., Smaill, F.M., Ralph, E.D., Tharao, W.E., Loutfy, M.R., \& the Ontario HIV Fertility Research Team (2014). The importance of motherhood in HIV-positive women of reproductive age in Ontario, Canada. AIDS Care: Psychological and Socio-medical Aspects of AIDS/HIV, 26(6), 777-784.

*Landsman, G. (2005). Mothers and models of disability. Journal of Medical Humanities, 26(2/3), 121-139.

Mahler, J., \& Saugeres, L. (2007). To be or not to be a mother? Women negotiating cultural representations of mothering. Journal of Sociology, 43(1), 5-21.

Malacrida, C., \& Boulton, T. (2012). Women's perceptions of childbirth "choices": Competing discourses of motherhood, sexuality, and selflessness. Gender \& Society, 26(5), 748-772.

*McKeever, P., \& Miller, K-L. (2004). Mothering children who have disabilities: A Bourdieusian interpretation of maternal practices. Social Science \& Medicine, 59, 1177-1191.

McQuillan, J., Griel, A., Shreffler, K., \& Tichenor, V. (2008). The importance of motherhood among women in the contemporary United States. Gender and Society, 22, 477-496.

Mercer, R.T. (2004). Becoming a mother versus mother role attainment. Journal of Nursing Scholarship, 36(3), 226-232. 
Milgrom, J., Gemmill, A.W., Bilszta, J.L., Hayes, b., Barnett, B., Brooks, J., Erikcsen, j., ellwood, d., \& Buist, A. (2008). Antenatal risk factors for postnatal depression: A large prospective study. Journal of Affective Disorders, 108, 147-157.

Morgan, K.J., \& Eastwood, J.G. (2014). Social determinants of maternal self-rated health in South Western Sydney, Australia. BioMed Central Research Notes, 7(51), 1-7.

Muňoz, L.A., Sanchez, X., Arcos, E., Vollrath, A., \& Bonatti, C. (2013). The motherhood experience in the context of social vulnerability: A comprehensive approach to social phenomenology. Revista Latino-Americana de Enfermagem, 21(4), 1-8.

Nelson, A.M. (2003). Transition to motherhood. Journal of Obstetric, Gynecologic, and Neonatal Nursing, 32(4), 465-477.

*Nicholl, H.M., \& Begley, C.M. (2012). Explicating caregiving by mothers of children with complex needs in Ireland: A phenomenological study. Journal of Pediatric Nursing, 27, 642-651.

Palisano, R.J., Chiarello, L.A., King, G.A., Novak, I., Stoner, T., \& Fiss, A. (2012). Participation-based therapy for children with physical disabilities. Disability and Rehabilitation, 34(12), 1041-1052.

Park, N.K., \& Hill, P.W. (2014). Is adoption an option? The role of importance of motherhood and fertility help-seeking in considering adoption. Journal of Family Issues, 35(5), 601-626.

Rallis, S., Skouteris, H., McCabe, M., \& Milgrom, J. (2014). The transition to motherhood: Towards a broader understanding of perinatal distress. Women and Birth, 27, 68-71.

Read, D.M.Y., Crockett, J., \& Mason, R. (2012). "It was a horrible shock": The experience of motherhood and women's family size preferences. Women's Studies International Forum, 35, 12-21.

*Redmond, B., \& Richardson, V. (2003). Just getting on with it: Exploring the service needs of mothers who care for young children with severe/profound and life-threatening intellectual disability. Journal of Applied Research in Intellectual Disabilities, 16, 205-218.

*Rogers, C. (2007). Disabling a family? Emotional dilemmas experienced in becoming a parent of a child with learning disabilities. British Journal of Special Education, 34(3), 136-143.

*Roskam, I., \& Schelstraete, M-A. (2006). A qualitative analysis of mothers' childbearing behaviour towards their disabled child. Research in Developmental Disabilities, 28, 130-144.

Sevón, E. (2012). 'My life has changed, but his life hasn't': Making sense of the gendering of parenthood during the transition to motherhood. Feminism \& Psychology, 22(1), 60-80.

*Seymour, M., Wood, C., Giallo, R., \& Jellett, R. (2013). Fatigue, stress and coping in mothers of children with an autism spectrum disorder. Journal of Autism Developmental Disorder, 43, 15471554.

Shelton, N., \& Johnson, S. (2006). 'I think motherhood for me was a bit like a double-edged sword': The narratives of older mothers. Journal of Community and Applied Social Psychology, 16, 316-330. 
Strobe statement. (2007). Available from: http://www.strobe-

statement.org/index.php?id=available-checklists Accessed 11 August 2014.

Tong, A., Sainsbury, P., \& Craig, J. (2007). Consolidated criteria for reporting qualitative research (COREQ): a 32-item checklist for interviews and focus groups. International Journal for Quality in Health Care, 19(6), $349-357$.

Van Bussel, J., Spitz, B., \& Demyttenaere, K. (2008). Anxiety in pregnant and postpartum women. An exploratory study of the role of maternal orientations. Journal of Affective Disorders, 114(1), 232242.

Van Bussel, J., Spitz, B., \& Demyttenaere, K. (2010). Childbirth expectations and experiences and associations with mothers' attitudes to pregnancy, the child and motherhood. Journal of Reproductive and Infant Psychology, 28(2), 143-160.

Von Elm, E., Ahman, D.G., Egger, M., Pocock, S.J., Gǿtzsxhe, P.C., \& Vandenbroucke, J.P. (2007). The strengthening the reporting of observational studies in epidemiology (STROBE) statement: guidelines for reporting observational studies. Bulletin of the World Health Organization, 85, 867-872.

Watson, D., Abbott, D., \& Townsley, R. (2006). Listen to me, too! Lessons from involving children with complex healthcare needs in research about multi-agency services. Child: Care, Health and Development, 33(1), 90-95.

Wilson, H., \& Huntingdon, A. (2006). Deviant (m)others: The construction of teenage motherhood in contemporary discourse. Journal of Social Policy, 35(1), 59-76.

Woolfson, L. (2004). Family well-being and disabled children: A psychosocial model of disabilityrelated child behaviour problems. British Journal of Health Psychology, 9, 1-13. 
Table 1 Articles included in the review - result of the quality appraisal of the articles

\begin{tabular}{|c|c|c|c|c|}
\hline $\begin{array}{l}\text { Study (author, year and } \\
\text { country }\end{array}$ & Aim of the study & Participants and data- collection time & $\begin{array}{l}\text { Result of quality } \\
\text { appraisal }\end{array}$ & $\begin{array}{l}\text { Data-collection } \\
\text { instrument/questionnaire }\end{array}$ \\
\hline $\begin{array}{l}\text { Redmond \& Richardson } \\
\text { 2003, Ireland }\end{array}$ & $\begin{array}{l}\text { To explore mothers' views of } \\
\text { the usefulness of the } \\
\text { financial, practical and } \\
\text { emotional support being } \\
\text { offered to them and their } \\
\text { suggestions for service } \\
\text { improvements }\end{array}$ & $\begin{array}{l}17 \text { mothers of children aged four years } \\
\text { and younger with severe/profound } \\
\text { intellectual disability. } \\
\text { The mothers in this study were the } \\
\text { primary carer as the children were living } \\
\text { full-time in the family home. } \\
\text { Data-collection time is unclear }\end{array}$ & COREQ 15/32 & $\begin{array}{l}\text { Semi-structured interviews, } \\
\text { General Health } \\
\text { Questionnaire }\end{array}$ \\
\hline $\begin{array}{l}\text { Mckeever \& Miller 2004, } \\
\text { Canada }\end{array}$ & $\begin{array}{l}\text { To use Pierre Bourdieu's } \\
\text { central concepts to reanalyse } \\
\text { three independent } \\
\text { qualitative studies focused } \\
\text { on mothers' accounts of } \\
\text { raising children with severe } \\
\text { disabling conditions }\end{array}$ & $\begin{array}{l}\text { Three research studies in } 1991 \text { and } 1997 . \\
66 \text { mothers living in the same Canadian } \\
\text { city. } \\
\text { Study one - } 25 \text { biological mothers of } \\
\text { children, aged six months to } 13 \text { years } \\
\text { with severe chronic illness or disabilities } \\
\text { who were dependent on technologies } \\
\text { such as ventilators, feeding pumps and } \\
\text { dialysis equipment. } \\
\text { Only nine mothers were working - either } \\
\text { full-time or part-time. } \\
\text { Study two - } 22 \text { biological mothers of } \\
\text { children with severe or moderate } \\
\text { disabilities related to spina bifida or } \\
\text { cerebral palsy and who required the use } \\
\text { of mobility aids. } \\
\text { The mean age of the children was seven } \\
\text { years. } \\
\text { Study three }-19 \text { biological mothers of } \\
\text { children aged four to } 13 \text { years who had }\end{array}$ & COREQ 12/32 & Secondary analysis \\
\hline
\end{tabular}




\begin{tabular}{|c|c|c|c|c|}
\hline $\begin{array}{l}\text { Study (author, year and } \\
\text { country }\end{array}$ & Aim of the study & Participants and data- collection time & $\begin{array}{l}\text { Result of quality } \\
\text { appraisal }\end{array}$ & $\begin{array}{l}\text { Data-collection } \\
\text { instrument/questionnaire }\end{array}$ \\
\hline & & $\begin{array}{l}\text { used a novel walker during the preceding } \\
\text { year. }\end{array}$ & & \\
\hline Landsman 2005, USA & $\begin{array}{l}\text { To examine how mothers of } \\
\text { very young disabled children } \\
\text { understand their children } \\
\text { and define disability in } \\
\text { relation to publicly available } \\
\text { discourses of disability and } \\
\text { identity }\end{array}$ & $\begin{array}{l}60 \text { mothers of children under the age of } \\
\text { five who were newly diagnosed with a } \\
\text { disability. } \\
130 \text { sessions where young children with } \\
\text { their mothers present were evaluated by } \\
\text { one or more developmental physician. } \\
\text { One third of the women were } \\
\text { interviewed a year later to provide } \\
\text { comparison between the narratives } \\
\text { collected relatively soon after a child's } \\
\text { diagnosis and narratives reflecting the } \\
\text { experience of mothering over time. } \\
\text { Data-collection time is unclear. }\end{array}$ & COREQ 16/32 & $\begin{array}{l}\text { Observation } \\
\text { In-depth interviews }\end{array}$ \\
\hline Rogers 2007, UK & $\begin{array}{l}\text { To highlight emotional } \\
\text { dilemmas parents of children } \\
\text { with learning disabilities } \\
\text { experience }\end{array}$ & $\begin{array}{l}24 \text { parents living in the south of England. } \\
\text { All the parents had one or more child } \\
\text { with at least one of the following } \\
\text { diagnoses: autistic spectrum disorder, } \\
\text { Asperger's syndrome, Down's syndrome, } \\
\text { cerebral palsy, attention } \\
\text { deficit/hyperactivity disorder, learning }\end{array}$ & COREQ 17/32 & Unstructured interviews \\
\hline
\end{tabular}




\begin{tabular}{|c|c|c|c|c|}
\hline $\begin{array}{l}\text { Study (author, year and } \\
\text { country }\end{array}$ & Aim of the study & Participants and data- collection time & $\begin{array}{l}\text { Result of quality } \\
\text { appraisal }\end{array}$ & $\begin{array}{l}\text { Data-collection } \\
\text { instrument/questionnaire }\end{array}$ \\
\hline & & $\begin{array}{l}\text { disabilities, dyslexia, dyspraxia, speech } \\
\text { and language difficulties and emotional } \\
\text { and behavioural difficulties Unstructured } \\
\text { interviews were conducted between } \\
\text { 2001and } 2003 \text {. }\end{array}$ & & \\
\hline $\begin{array}{l}\text { Roskam \& Schelstraete 2007, } \\
\text { Belgium }\end{array}$ & $\begin{array}{l}\text { To improve accuracy in the } \\
\text { study of the mothers' } \\
\text { childrearing behaviour by } \\
\text { means of a content analysis } \\
\text { of the mothers' reports } \\
\text { To determine if mothers } \\
\text { adapt their childrearing } \\
\text { behaviour to the child's } \\
\text { disability }\end{array}$ & $\begin{array}{l}31 \text { French-speaking mothers with a } \\
\text { disabled child in the three-to-six age } \\
\text { range. } \\
\text { Children were divided into three groups: } \\
\text { mentally retarded, multiple disabilities, } \\
\text { and sensory disabilities. } \\
\text { Professionals from } 13 \text { Services d'Aide } \\
\text { Précoce interviewed the mothers. } \\
\text { Time of data-collection is unclear. }\end{array}$ & COREQ 14/32 & $\begin{array}{l}\text { Semi-structured interviews, } \\
\text { Bipolar Rating Scale based on } \\
\text { the Five Factor Model }\end{array}$ \\
\hline Fiamenghi et al. 2010, Brazil & $\begin{array}{l}\text { To analyse in detail the } \\
\text { interactions of two mothers } \\
\text { and their disabled infants }\end{array}$ & $\begin{array}{l}\text { Two mothers and two disabled infants. } \\
\text { First dyad - } 25 \text {-year old mother and } 20 \text { - } \\
\text { month-old Down syndrome daughter. } \\
\text { The mother was working. } \\
\text { Second dyad - } 26 \text {-year old mother with } \\
20 \text {-month-old hypotonic son. The mother } \\
\text { was not working. } \\
\text { Data-collection time is unclear. }\end{array}$ & STROBE $12 / 22$ & DVD footage \\
\hline Bingham et al. 2012, USA & $\begin{array}{l}\text { To investigate mothers' } \\
\text { memories of their children's } \\
\text { initial disability diagnosis }\end{array}$ & $\begin{array}{l}\text { Six mothers of children with disabilities, } \\
\text { birth to age three years. } \\
\text { Five of the mothers were working and } \\
\text { one stayed at home. } \\
\text { Data-collection time is unclear }\end{array}$ & COREQ 22/32 & $\begin{array}{l}\text { Interviews, } \\
\text { Revised Ways of Coping } \\
\text { questionnaire, } \\
\text { Field notes }\end{array}$ \\
\hline
\end{tabular}




\begin{tabular}{|l|l|l|l|l|}
\hline $\begin{array}{l}\text { Study (author, year and } \\
\text { country }\end{array}$ & Aim of the study & Participants and data- collection time & $\begin{array}{l}\text { Result of quality } \\
\text { appraisal }\end{array}$ & $\begin{array}{l}\text { Data-collection } \\
\text { instrument/questionnaire }\end{array}$ \\
\hline $\begin{array}{l}\text { Nicholl \& Begley 2012, } \\
\text { Ireland }\end{array}$ & $\begin{array}{l}\text { To explore mothers' } \\
\text { experiences of caring for a } \\
\text { child with complex needs }\end{array}$ & $\begin{array}{l}\text { 17 mothers of children with complex } \\
\text { needs. The age of the children are } \\
\text { described as under five. } \\
\text { Data-collection time is unclear. }\end{array}$ & COREQ 19/32 & $\begin{array}{l}\text { Unstructured interviews, } \\
\text { Diaries }\end{array}$ \\
\hline Seymour et al. 2012, USA & $\begin{array}{l}\text { To investigate the } \\
\text { relationship between child } \\
\text { behaviour problems and } \\
\text { stress in mothers of young } \\
\text { children with an Autism } \\
\text { Spectrum Disorder. }\end{array}$ & $\begin{array}{l}65 \text { mothers of children aged two to five } \\
\text { years with autism spectrum disorder. } \\
\text { The mothers were either in part-time or } \\
\text { casual employment. } \\
\text { Data-collection time is unclear. }\end{array}$ & STROBE 16/22 & $\begin{array}{l}\text { Demographic and Family } \\
\text { Background Questionnaire, } \\
\text { Brief Developmental } \\
\text { Behavior Checklist-P24, } \\
\text { Depression, anxiety and } \\
\text { stress scale-21, } \\
\text { Fatigue assessment scale } \\
\text { adapted version, } \\
\text { Brief COPE }\end{array}$ \\
\hline
\end{tabular}


Table 2 Becoming mothers of children with disabilities themes and references

\begin{tabular}{|l|l|}
\hline Theme & References \\
\hline Transition to motherhood in the inside world at home & Bingham et al. 2012; Fiamenghi et al. \\
& 2010; Green 2007; Landsman 2005; \\
& McKeever \& Miller 2004; Nicholl \& \\
& Begley 2012; Redmond \& Richardson \\
& 2003; Rogers, 2007; Roskam \& \\
& Schelstraete 2007; Seymour et al. 2013 \\
\hline Transition to motherhood in the outside world external to & Bingham et al. 2012; Fiamenghi et al. \\
home & 2010; Green 2007; Landsman 2005; \\
& McKeever \& Miller 2004; Nicholl \& \\
& Begley 2012; Redmond \& Richardson \\
& 2003; Rogers, 2007 \\
\hline Transition to motherhood in the 'going-between' world of & Bingham et al. 2012; Nicholl \& Begley \\
travelling between the two worlds & 2012; Rogers 2007 \\
\hline
\end{tabular}

